\title{
Editorial
}

\section{O mercado de trabalho crescente da Bioética}

Há algum tempo atrás fui entrevistado em um programa semanal da Rádio CBN que trata do mercado de trabalho relacionado com os diversos setores de atividade profissional. Tendo conhecimento do crescimento e difusão da Bioética no contexto internacional e também no brasileiro, a produção do programa pautou, oportunamente, o tema para informação e discussão. Apesar de trabalhar com a Bioética há quase 20 anos, confesso que não havia pensado até então no assunto e me vi obrigado a desenvolver um raciocínio lógico sobre os diversos setores que ela cobre e para os quais é útil. Acabei me surpreendendo com os achados, pois o campo é mais promissor do que a uma primeira vista pode parecer.

Um primeiro setor imediatamente lembrado é aquele relacionado com os mais diferentes tipos de comissões, comitês ou conselhos de ética, que apresentam quatro variedades, cada um deles com características e funções próprias. O principal é aquele que incorpora os Conselhos Nacionais, Estaduais e Municipais de Bioética e também de Biossegurança, ainda pouquíssimo desenvolvidos no Brasil. Um segundo tipo de organismo inclui os Conselhos e Comitês relacionados com a Ética em Pesquisa com Seres Humanos e também com Animais, em plena expansão no país. Um terceiro - que na Espanha, por exemplo, existe por lei, com funcionamento obrigatório nos hospitais a partir de um determinado número de leitos - são os Comitês de Bioética Institucional ou de Bioética Clínico-Hospitalar propriamente dita, também surpreendentemente escassos por aqui. E, por fim, os Conselhos de Ética Profissional, muito difundidos e direcionados a tratar questões éticas relacionadas aos conflitos internos e ao exercício das diversas profissões do setor saúde e outros afins, que nos últimos anos, além dos referenciais deontológicos também começam a incorporar os conhecimentos relacionados à Bioética. A composição de todos estes organismos deve ser obrigatoriamente multiprofissional (com exceção dos de ética profissional, naturalmente) e pluralista, com referência à exigência de visões morais diversas de parte de seus componentes, o que expande a oferta de trabalho.

Por outro lado, uma formação adequada em Bioética amplia o horizonte de reflexão e prática tanto dos membros dos colegiados acima referidos, como de todos trabalhadores das profissões que, de uma forma ou outra - direta ou indiretamente - tem relação com a Bioética, sejam elas da área das ciências biomédicas e da saúde, das ciências sociais e humanas ou das ciências da terra e da natureza. Um preparo conveniente na matéria favorece tomadas de decisão mais equilibradas e pautadas na 
ponderação, no diálogo, na argumentação e na busca da construção mais harmônica e equilibrada de decisões e consensos, quando possível.

Um segundo setor do mercado de trabalho para aqueles que decidiram se especializar em Bioética é aquele dos profissionais que atuam no serviço público de modo geral - ministérios, secretarias estaduais ou municipais de saúde, educação, direitos humanos, ciência e tecnologia, meio ambiente, agricultura, previdência social, justiça... - autarquias, hospitais públicos e privados, organizações não-governamentais, etc., que certamente desenvolverão melhor suas atividades se puderem contar com uma base adequada de conhecimento na matéria. Mesmo as decisões gerenciais nestes diferentes e variados campos de atuação acima referidos, podem ser mais justas e sensatas a partir de uma boa base de sustentação ético-acadêmica em Bioética.

O terceiro exemplo de espaço que a formação específica proporciona no mercado de trabalho é aquele relacionado com a formação, além de pesquisadores, de professores de Bioética em todos os níveis: primário, secundário e universitário. Pode chamar a atenção das pessoas desavisadas, a possível inclusão da bioética para breve também nos currículos do ensino fundamental e médio, além das universidades, nas quais já vem acontecendo de modo crescente, apesar da formação pontual ainda frágil de parte dos docentes da disciplina. Com relação às duas primeiras situações - ensino fundamental e médio - convém recordar que a Declaração sobre Bioética e Direitos Humanos da UNESCO, firmada em Paris em 2005 pelo Brasil conjuntamente com outros 190 países, preconiza no seu Artigo 23 que “... os Estados devem envidar esforços para promover a formação e educação em bioética em todos os níveis, bem como estimular programas de disseminação de informação e conhecimento sobre bioética".

Enfim, com menos de 40 anos de vida, a Bioética vem ampliando seu campo de atuação, proporcionando significativo espaço profissional no mercado de trabalho público e privado àqueles(as) que a ela decidiram se dedicar.

\section{Volnei Garrafa Editor Chefe - RBB}

